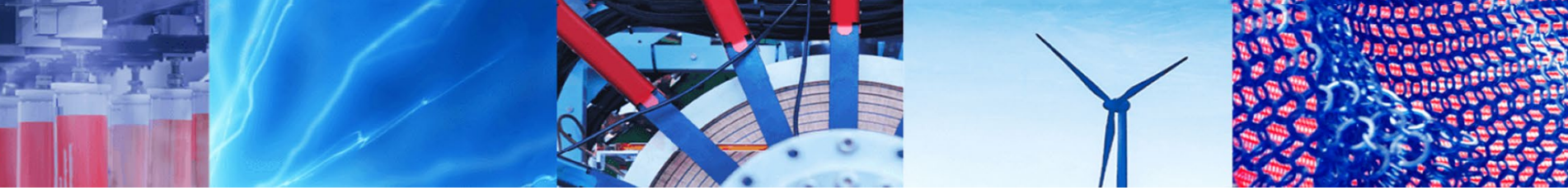

Research Article

\title{
Alternative methods for dark fermentation course analysis
}

\author{
Edyta Słupek $^{1}$ (1) $\cdot$ Karolina Kucharska ${ }^{1} \cdot$ Jacek Gębicki ${ }^{1}$
}

(c) The Author(s) 2019 OPEN

\begin{abstract}
Dark fermentation course analysis is crucial, as complexed matrix of gaseous components may be formed and revealed during the process. The paper considers key issues related to the microbiological process in which complex organic substances are transformed into hydrogen. For the purposes of hydrogen generation, the application of wastewater mixed sludge pre-treated according to Faloye method (Faloye et al. in Int J Hydrog Energy 38:11765-11773, 2013. https ://doi.org/10.1016/j.ijhydene.2013.06.129; Int J Hydrog Energy 39:5607-5616, 2014. https://doi.org/10.1016/j.ijhyd ene.2014.01.163) was applied. The main risk of by-product formation is related to the presence of methanogens, i.e., Archea, in the sludge. The application of gaseous chromatography confirmed the presence of hydrogen during the initial, lag and log phases of the culture and methane in the late logarithmic death phase of the culture. However, other fermentation gaseous products' presence was not confirmed, as their concentration was under the limit of detection. Therefore, a revision regarding the application of matrix sensors was proposed, and the levels of gases able to be measured using both gas chromatography and matrix sensors were conducted. The criteria of matrix sensors' selection should include the selectivity not only for the hydrogen, hydrogen sulfide or methane, but also the sensitivity to the response of other gases contained in the mixture-ammonium, carbon dioxide and oxygen. A comprehensive combination of commercially available sensors and their applicability for the purposes of dark fermentation course analysis was presented on the basis of the levels of gas concentrations in the generated gas mixture.
\end{abstract}

Keywords Dark fermentation $\cdot$ Matrix sensors $\cdot$ Biogas $\cdot$ Hydrogen $\cdot$ Bioconversion

\section{Introduction}

Fermentation is a group of biological process of decomposition of organic substances leading to stabilization of sewage sludge, waste materials and residues. Diversified phenomena occur during fermentation processes, as a result of the entire range of organic compounds degradation with the formation of, that is, methane, ethanol or hydrogen and carbon dioxide [3-5]. Currently, fermentation is used in four main sectors of waste processing including treatment of urban wastewater, agricultural waste, food and biomass industries and processing of the organic fraction of municipal solid waste [5-7]. Biomass residues of wide origin are considered as great potential materials for biofuels production $[3,8,9]$. The main directions in biomass to biofuels transformation are presented in Fig. 1.

The objective of this paper is the research on dark fermentation to biohydrogen and the factors affecting this process. Hydrogen is the most widespread element in nature. Non-renewable fossil raw materials such as crude oil (about 50\%), natural gas (30\%) and coal (15\%) [10, $11]$ are the most commonly used sources for hydrogen production. Among the leading technologies for hydrogen production using conventional energy sources are steam reforming of natural gas and crude oil, the catalytic decomposition of natural gas, partial oxidation of heavy hydrocarbon fractions of crude oil and gasification of coal or coke. Unfortunately, these methods are

Edyta Słupek, edyta.slupek@pg.edu.pl | 'Department of Process Engineering and Chemical Technology, Faculty of Chemistry, Gdańsk University of Technology, Narutowicza 11/12 Street, 80-233 Gdańsk, Poland.

SN Applied Sciences (2019) 1:469 | https://doi.org/10.1007/s42452-019-0488-2

Received: 30 January 2019 / Accepted: 12 April 2019 / Published online: 19 April 2019 
Fig. 1 Main directions in biomass to biofuels transformation

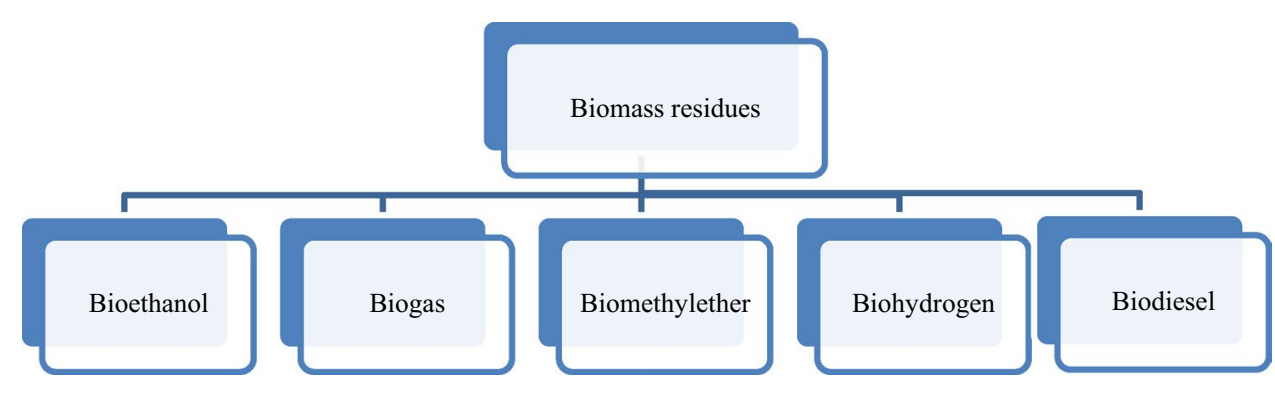

highly energy-intensive, require the use of high temperatures $\left(>700^{\circ} \mathrm{C}\right)$ and pollute the environment due to the carbon, sulfur and nitrogen oxides emission [12, 13]. Another important industrial process for the production of hydrogen is the electrolysis of water, under the influence of electric current. This method, however, requires delivery of electricity from coal and natural gas or nuclear power plants. Therefore, non-renewable fossil fuels are used indirectly as raw materials. It is estimated that the cost of electricity represents about $80 \%$ of the total cost of the process [14], and the production of hydrogen by electrolysis of water is currently about 3.5 times more expensive compared to natural gas steam reforming [15]. The advantage of electrolysis is, however, no emission of carbon dioxide into the atmosphere. Other hydrogen production methods, such as thermochemical or photocatalytic decomposition of water and a high-temperature plasma technology separation of hydrocarbons into hydrogen and carbon, are the subject of intensive research into their development.

Hydrogen conversion from biomass may be a good alternative if biotechnological methods are used. The biological technologies of producing hydrogen include processes involving light energy: direct and indirect biophotolysis and photofermentation. The second group are the biological processes in the absence of light: dark fermentation, bioelectrolysis and bioconversion of carbon monoxide [16]. The dark fermentation is considered as the most promising method for biological hydrogen production. Carbohydrate substrates are converted in the absence of light by bacteria in the process of anaerobic respiration. The raw materials for the fermentation may be glycerin or simple sugars as well as cellulose or starch, which can be hydrolyzed to monosaccharides $[17,18]$. In particular, it is desirable to use by-products, waste products rich in glycerol, starch and cellulose from agri-food, wood and paper industries to produce the second-generation biohydrogen using microbial metabolic processes. While the biomass contains high amounts of polysaccharides, which can be processed into hydrogen, it be an alternative to currently used processes, such as combustion or composting. Utilization of waste products that are difficult to dispose can contribute to environmental protection through both more rational use of natural resources and reducing the environmental load of such waste.

The first step in dark fermentation is glycolysis-glucose is fermented to pyruvate. Pyruvate is oxidized and transfers the electrons to ferredoxin [19]. Hydrogenase enzyme catalyzes the reduction of protons to hydrogen, using electrons from ferredoxin. The two types of fermentation pathways are distinguished depending on which chemical compound is the main product. Bacillus and Enterobacter species have the ability to metabolize via mixed acid fermentation [20-22]. In this case, butyric acid, butanol, hydrogen, carbon dioxide, acetic acid and other compounds such as acetone may be formed. Generation of a variety of final products decreases the amount of formed hydrogen. Theoretically stoichiometric amount of hydrogen produced during the complete decomposition of $1 \mathrm{~mol}$ of glucose may be equal to $12 \mathrm{~mol}$ (Eq. 1).

$\mathrm{C}_{6} \mathrm{H}_{12} \mathrm{O}_{6}+6 \mathrm{H}_{2} \mathrm{O} \rightarrow 12 \mathrm{H}_{2}+6 \mathrm{CO}_{2}$

Many factors such as inoculum, substrates, inorganic nutrients, reactor type and operational conditions like temperature and $\mathrm{pH}$ influence on the dark fermentation process course $[23,24]$. Depending on the factors, different courses of fermentation may occur. When pure bacterial cultures are used, hydrogen is the main product during fermentation. However, using different types of inoculum, i.e., mixed sludge, causes a risk of infection even if the inoculum is prepared according to the procedures described in the literature $[1,2]$.

Considering all the analytical problems that are encountered in gas analysis during dark fermentation, there is a growing interest in analytical tools that can identify and determine the amount and composition of emerging gases online. Till now, gas analysis is usually based on sampling and laboratory analysis via gas chromatography (GC) $[25,26]$. However, this approach may be time-consuming and expensive. A comparison of analytical- and sensorbased methods for gas analysis is given in Table 1 .

In the monitoring of gaseous/odorogenic compounds, primarily olfactometry is used. This is a method of quantifying the aromatic concentration expressed in European fragrances in a cubic meter using an instrument called an olfactometer [27]. Gas chromatography is another 
Table 1 Comparison of procedure complexity of analytical- and sensor-based approach

\begin{tabular}{lll}
\hline Parameters & $\begin{array}{l}\text { Analytical instrument } \\
\text { (i.e., GC) }\end{array}$ & Gas sensors \\
\hline Process control & Difficult & Easy \\
Resolution & Excellent & Comparable \\
Measurement & Instantaneous & Continuous \\
Mass production & Difficult & Easy \\
Cost & Very high & Fair \\
\hline
\end{tabular}

technique used to analyze gas mixtures. It is used to separate and identify chemical compounds from a mixture. However, multi-sensor devices allow on a quick and in a easy way to detect and determine the intensifying odorogenic gases in a near real time as well as substances lacking a perceptible odor (i.e., carbon dioxide and water vapor) [28-30].

\section{Experimental}

\subsection{Analytical methods}

The composition and analysis of biogas were carried out using a gas chromatograph (PerkinElmer AutoSystem $\mathrm{XL}$ ) with a Porapak Q column (100-120 mesh $6.5 \mathrm{~m} \times 1 / 8$, pressure $200 \mathrm{kPa}$ ) and an oven temperature of $60^{\circ} \mathrm{C}$. The studies were carried using a thermo-conductivity detector $\left(T C D\right.$, temperature $\left.100^{\circ} \mathrm{C}\right)$. Nitrogen with a flow of $30 \mathrm{~mL} / \mathrm{min}$ was used as the carrier gas. The volume of the analyzed sample was $0.2 \mathrm{~mL}$. During the analysis ( $15 \mathrm{~min}$ ), TurboChrom software was used.

\subsection{Dark fermentation}

Dark fermentation was carried out with the use of wastewater mixed sludge (municipal wastewater treatment plant, Saur Neptun Gdańsk, Poland) after Faloye procedure with respect to distilled glycerin as the sole carbon source. Faloye procedure allowed to destroy non-spherical microorganisms [1, 2]. Dark fermentation was carried in triplicate in sterile $1200 \mathrm{~mL}$ glass bioreactors with a working volume of $1000 \mathrm{~mL}$ fermentation broth and under regulated $\mathrm{pH}$ conditions as described in the previous study $[26,31,32]$. The initial fermentation broth was composed of $900 \mathrm{~mL}$ of $20.0 \mathrm{~g} / \mathrm{L}$ solution of Buffered Peptone Water (Biomaxima Gdańsk, Poland) and $5.5 \mathrm{~g} / \mathrm{L}$ distilled glycerin as a sole carbon source. Control (negative) was carried in $20.0 \mathrm{~g} / \mathrm{L}$ solutions of Buffered Peptone Water (Biomaxima Gdańsk, Poland) without glycerin and glucose control with Thioglycollate (Biomaxima Gdańsk, Poland) with the addition of $5.5 \mathrm{~g} / \mathrm{L}$ of glucose. In each flask, $100 \mathrm{~mL}$ of Faloyepre-treated inoculum was introduced to the broth at $37^{\circ} \mathrm{C}$ (Table 2). The $\mathrm{pH}$ of fermentation broth was adjusted to 7.00 with $1 \mathrm{M} \mathrm{NaOH}$. Before inoculation, anaerobic conditions were created by purging the reactors with sterile nitrogen (Linde, purity $99.98 \%$ ) for $60 \mathrm{~min}$. Operational setpoints were set at $37^{\circ} \mathrm{C}$ and $320 \mathrm{RPM}$ (rotations/min) for temperature and agitation, respectively [26]. The composition of fermentation broths is presented in Table 2.

\section{Results and discussion}

Anaerobic digestion is a multi-step process carried out by consortia of highly diversified microorganisms and requires strictly anaerobic conditions. Such conditions enable the transformation of organic matter into carbon dioxide and methane, if methanogenesis is inactive. In the first stage of $A D$, organic matter, i.e., glycerin, is hydrolyzed; then, in the second stage, it is converted via fermentative bacteria to a mixture of minor products. In the third stage, acetogenic bacteria convert minor products to acetate, $\mathrm{CO}_{2}$ and $\mathrm{H}_{2}$. Consequently, as the terminal phase of the culture occurs, methanogenesis takes place [33]. Different microbial populations have specific optimum working conditions and are inhibited by several process parameters such as $\mathrm{pH}$, temperature, alkalinity, concentration of free ammonia, hydrogen, sodium, potassium, volatile fatty acids (abr.VFA) or heavy metals.

The changes in the composition of gas formed during dark fermentation on diversified feed material are
Table 2 Composition of tested fermentation broths

\begin{tabular}{llll}
\hline Components & \multicolumn{2}{l}{ Fermentation broth } & \\
\cline { 2 - 4 } & Glycerin broth & Glucose control & Negative control \\
\hline Buffered Peptone Water $900 \mathrm{~mL}$ & $20.0 \mathrm{~g} / \mathrm{L}$ & - & $20.0 \mathrm{~g} / \mathrm{L}$ \\
Thioglycollate broth alternative & - & $29.0 \mathrm{~g} / \mathrm{L}$ & - \\
Glucose & $0.5 \mathrm{~g} / \mathrm{L}$ & $5.5 \mathrm{~g} / \mathrm{L}$ & $0.5 \mathrm{~g} / \mathrm{L}$ \\
Glycerin & $5.5 \mathrm{~g} / \mathrm{L}$ & - & - \\
Faloye-pre-treated inoculum & $100 \mathrm{~mL}$ & $100 \mathrm{~mL}$ & $100 \mathrm{~mL}$ \\
Total volume & $1000 \mathrm{~mL}$ & & \\
\hline
\end{tabular}


presented in Fig. 2. During the experiment, all mentioned stages could be observed. When glucose was used as a sole carbon source (glucose control), no induction time concerning dark fermentation was observed. High concentrations of hydrogen were detected after $20 \mathrm{~h}$ of culture. The production of hydrogen lasted $96 \mathrm{~h}$, after which the termination could be observed, as the hydrogen concentration dropped. In a similar broth, however, with a relatively lower glucose content (negative control), a small production of hydrogen was observed and methane was not detected. The course of dark fermentation for glycerin as a sole carbon source revealed an induction time. After $20 \mathrm{~h}$ of dark fermentation, the initiation phase passed to logarithmic growth phase. Hydrogen was generated till ca. $75 \mathrm{~h}$ of culture. In ca. $75 \mathrm{~h}$ of the culture, the hydrogen's terminal phase occurred and methanogens started to produce methane. The concentrations of methane obtained from the culture were even higher than the ones obtained for hydrogen. The authors expected to detect other gases, i.e., $\mathrm{H}_{2} \mathrm{~S}$; however, its concentration was lower than the limits of detection in the used GC; therefore, a need to search for alternative gas composition determination has occurred. As the hydrogen productivity is concerned, it is crucial to determine the moment, when the hydrogen concentration drops and $\mathrm{CH}_{4}$ and $\mathrm{H}_{2} \mathrm{~S}$ production occurs. The authors have placed a red line in the time point, for which the methane concentration starts to increase. From that moment, the produced gas stream needs to be separated, in order to keep a high purity of previously formed hydrogen. Unfortunately, the applied GC technique did not allow to determine the $\mathrm{H}_{2} \mathrm{~S}$ concentration, as its level was under the limit of detection (abr. LOD). The same situation has taken place for other fermentation gases, i.e., ammonia, carbon monoxide and oxygen. In other studies,

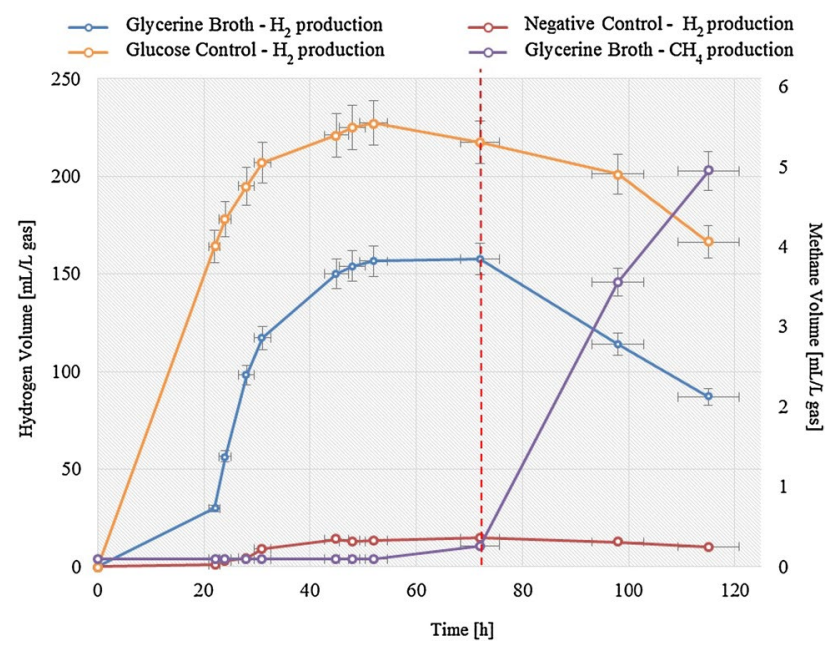

Fig. 2 Changes in gas composition occurring during dark fermentation with respect to hydrogen and methane similar hydrogen productivity during dark fermentation was observed [34-36]. However, the data in the literature are very hard to compare, as they are normalized and often received in a diversified broths, volumes and with the application of varied process parameters, i.e., $\mathrm{pH}$, temperature, agitation of even the type of wastewater sludge.

A delay in the GC analysis results may cause a delay in the hydrogen and methane streams separation. Therefore, the authors conducted that in order to carry out further tests, a review of commercially available gas sensors for the purposes of dark fermentation course analysis and gas composition determination is required.

On the basis of described research, the authors decided that further tests on the composition of fermentative gaseous products require alternative methods, i.e., gas sensors. Gas composition may be carried using a MOS type sensor, with $\mathrm{CuO}$ [37], which meets the criteria for typical fermentation gas measurements (Fig. 3). The sensor is selective for $\mathrm{H}_{2} \mathrm{~S}$ concentration, but also has a relatively good response to other gases potentially contained in the tested mixture. Therefore, a research on sensors used for fermentation control needs to be carried. The criteria of selection should include the selectivity not only for the hydrogen, hydrogen sulfide or methane, but also the sensitivity to the response of other gases contained in the mixture-ammonia, carbon dioxide and oxygen.

Examples of commercially available gas sensors, that might be applicable for the gases obtained via dark fermentation, are presented in Table 2 . Sensors that are commercially available can be obtained from companies such as Duran Electronica and Figaro. Tables 3 and 4 show the examples of gas sensors and chromatographic methods with and their technical specifications, respectively. After analyzing the concentration ranges in which the sensors operate, it can be confirmed that readily available gas sensors meet the requirements for monitoring the dark fermentation process. However, as conducted during the fermentation, gas chromatography allows us to control only gases such as hydrogen, carbon dioxide and methane.

Comparison of the possibilities of detection concerning interesting fermentation gaseous products defined for both gas sensors (Table 3 ) and gas chromatography (Table 4) reveals that it was not possible to detect $\mathrm{H}_{2} \mathrm{~S}$ and $\mathrm{NH}_{3}$ using gas chromatography. However, it is possible to detect mentioned gases using sensor matrixes. The literature reports very low concentrations of $\mathrm{H}_{2} \mathrm{~S}$ and $\mathrm{NH}_{3}$ in the gaseous products [43-45]. Therefore, the limits of detection on the level 0-300 ppm for $\mathrm{H}_{2} \mathrm{~S}$ and 0-100 ppm for $\mathrm{NH}_{3}$ may be satisfactory for the control purposes of dark fermentation. After analyzing the concentration ranges in which the sensors operate, it can be confirmed that readily available gas sensors meet the requirements for monitoring the dark fermentation process. On the other hand, 
Fig. 3 Sensor response obtained for the CuO: 1 ppm $\mathrm{H}_{2} \mathrm{~S}$ and $100 \mathrm{ppm} \mathrm{CH}_{4}, \mathrm{NH}_{3}, \mathrm{H}_{2}$ $\mathrm{CO}, \mathrm{O}_{2}$ according to $[37,38]$

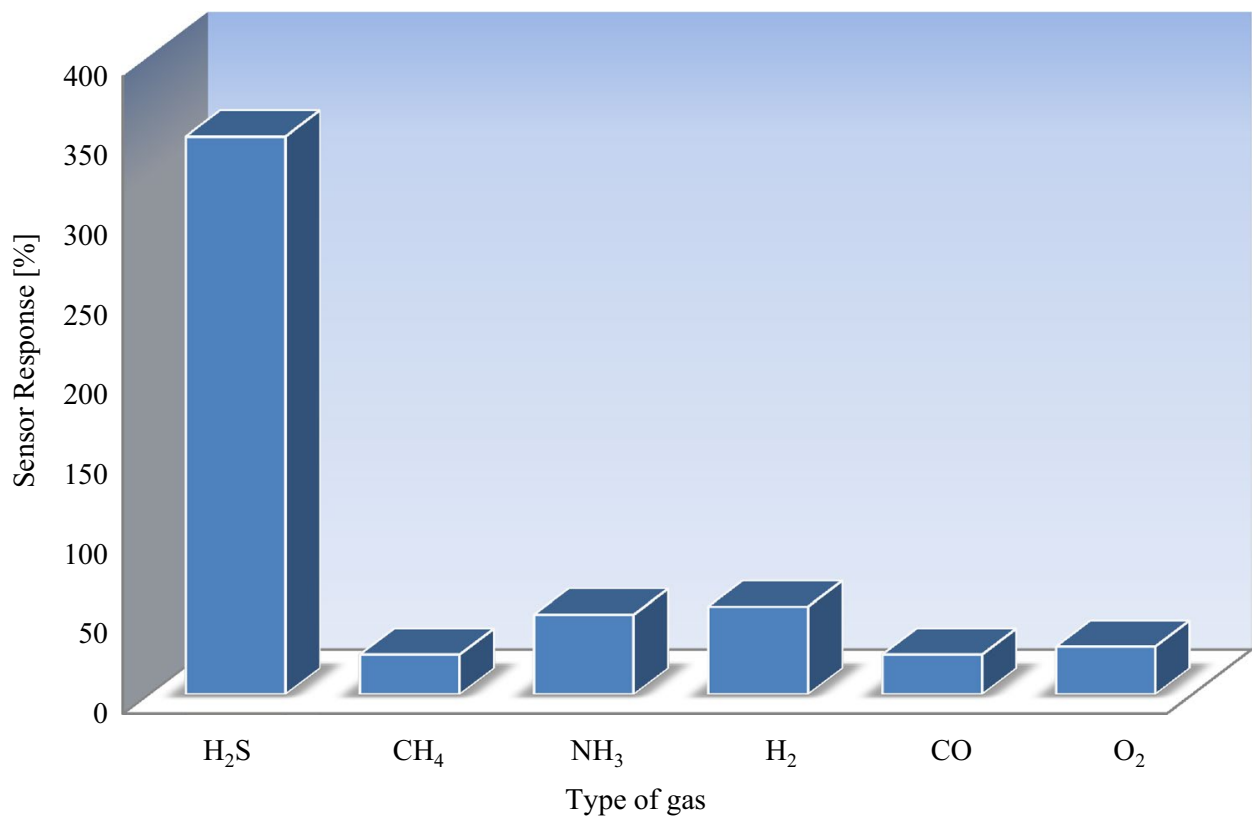

Table 3 Examples of commercially available gas sensors

\begin{tabular}{|c|c|c|c|c|c|c|}
\hline \multirow[t]{2}{*}{ Producer } & \multicolumn{5}{|l|}{ Duran Electronica } & \multirow{2}{*}{$\begin{array}{l}\text { Figaro } \\
\text { TGS2611 } \\
\text { MOS }\end{array}$} \\
\hline & SONDELTOX & & SSQNRSNH3LI & SIRYRSCO2rLI & SSQNRH2SSrLI & \\
\hline References & [39] & & {$[40]$} & {$[40]$} & {$[40]$} & {$[41]$} \\
\hline Gas type & $\mathrm{H}_{2} \mathrm{~S}$ & $\mathrm{H}_{2}$ & $\mathrm{NH}_{3}$ & $\mathrm{CO}_{2}$ & $\mathrm{H}_{2} \mathrm{~S}$ & $\mathrm{CH}_{4}$ \\
\hline \multicolumn{7}{|l|}{ Technical characteristics } \\
\hline Measurement range (ppm) & $0-300$ & $0-200$ & $0-100$ & $0-20.000$ & $0-100$ & $500-10.000$ \\
\hline Temperature range $\left({ }^{\circ} \mathrm{C}\right)$ & $-20^{\circ} \mathrm{C}$ to $+50^{\circ} \mathrm{C}$ & & $-10^{\circ} \mathrm{C}$ to $+50^{\circ} \mathrm{C}$ & & & - \\
\hline Pressure range & Atm $\pm 10 \%$ & & $80-110 \mathrm{kPa}$ & & & - \\
\hline Time of response (s) & T90<35 & T90 $<30$ & T90<30 & T90 $<15$ & T90 $<20$ & - \\
\hline
\end{tabular}

gas chromatography did not detect $\mathrm{H}_{2} \mathrm{~S}$ or $\mathrm{NH}_{3}$, so it only allows to control gases such as hydrogen, carbon dioxide and methane. The presence of other mentioned products needs to be confirmed in further research.

\section{Conclusions}

Complexed matrix of gaseous components may be formed and revealed during the dark fermentation process. The authors confirmed the presence of hydrogen, carbon dioxide, methane and oxygen during the process. Hydrogen was mainly generated in the initial, lag and log phase of the culture and methane in the late logarithmic death phase of the culture, only when glycerin was used a sole carbon source. However, other fermentation gaseous products' presence was not confirmed, as their concentration was under the limits of detection. The time point characterizing the moment when the methane production starts delivers some difficulties, as the gas chromatography delivers a slight delay regarding the results obtaining, as it is not a continuous method. As this time point is correlated with the appearance of $\mathrm{CH}_{4}$ and $\mathrm{H}_{2} \mathrm{~S}$, which occurs, when the metabolic pathway of bacteria and Archea take place, it seems crucial to determine other gases, not detectable using gas chromatography in the occurring levels. Therefore, a revision regarding the application of matrices sensors was proposed, and the levels of gases able to be measured using both gas chromatography and matrices sensors were conducted. The criteria of matrix sensors' selection should include the selectivity not only for the hydrogen, hydrogen sulfide or methane, but also the sensitivity to the response of other gases contained in 
Table 4 Examples of gas chromatography methods for gas analysis

\begin{tabular}{|c|c|c|c|c|c|}
\hline \multirow{4}{*}{$\begin{array}{l}\text { Producer } \\
\text { Reference } \\
\text { Gas type }\end{array}$} & \multicolumn{5}{|l|}{ Shimadzu } \\
\hline & \multicolumn{5}{|c|}{ GC/MS system (GCMS-QP2010 Plus) equipped with a CP-PoraPLOT Q-HT column } \\
\hline & \multicolumn{5}{|l|}{ [42] } \\
\hline & $\mathrm{H}_{2} \mathrm{~S}$ & $\mathrm{NH}_{3}$ & $\mathrm{H}_{2}$ & $\mathrm{CO}_{2}$ & $\mathrm{CH}_{4}$ \\
\hline \multicolumn{6}{|l|}{ Technical characteristics } \\
\hline Limit of detection (LOD) (ppm) & n.d. & n.d. & 335.9 & 5.1 & 3.3 \\
\hline Injection volume & $200 \mu \mathrm{L}$ & & & & \\
\hline Temperature & $100^{\circ} \mathrm{C}$ & & & & \\
\hline Head pressure & $38.0 \mathrm{kPa}$ & & & & \\
\hline Producer & \multicolumn{5}{|c|}{ PerkinEImer AutoSystem XL GC/FID/TCD equipped with a Porapak Q column } \\
\hline Reference & \multicolumn{5}{|l|}{ This study } \\
\hline Gas type & $\mathrm{H}_{2} \mathrm{~S}$ & $\mathrm{NH}_{3}$ & $\mathrm{H}_{2}$ & $\mathrm{CO}_{2}$ & $\mathrm{CH}_{4}$ \\
\hline \multicolumn{6}{|l|}{ Technical characteristics } \\
\hline Limit of detection (LOD) (ppm) & n.d. & n.d. & 120 & 1500 & 700 \\
\hline Injection volume & $200 \mu \mathrm{L}$ & & & & \\
\hline Temperature oven/TCD & $60^{\circ} \mathrm{C} / 100^{\circ} \mathrm{C}$ & & & & \\
\hline Head pressure & $200 \mathrm{kPa}$ & & & & \\
\hline
\end{tabular}

the mixture-ammonium, carbon dioxide and oxygen. A comprehensive combination of commercially available sensors and their applicability for the purposes of dark fermentation course analysis was presented on the basis of the levels of gas concentrations in the generated gas mixture. The authors conducted that the multi-sensor matrices may be a good alternative solution for fermentation gas measurement, especially when it is possible to apply them in a continuous matter. In addition, hydrogen sulfide and ammonia concentrations can be determined using gas sensors, which were under the limits of detection for gas chromatography. The application of sensor matrices for the dark fermentation course analysis needs to become a future step for the gas analysis and streams separation method development.

Author contributions ES and KK conceived, designed and carried the experiments. ES, KK, JG wrote the paper.

Funding This work was carried out within the framework of the project "Studies of alkaline hydrolysis of lignocellulosic biomass and conversion conditions of hydrolyzed products to biogas", supported financially by the National Science Center through the Grant UMO-2014/13/B/ST8/04258.

\section{Compliance with ethical standards}

Conflict of interest The authors declare no conflict of interest. The founding sponsors had no role in the design of the study; in the collection, analyses, or interpretation of data; in the writing of the manuscript; and in the decision to publish the results.
Open Access This article is distributed under the terms of the Creative Commons Attribution 4.0 International License (http://creativeco mmons.org/licenses/by/4.0/), which permits unrestricted use, distribution, and reproduction in any medium, provided you give appropriate credit to the original author(s) and the source, provide a link to the Creative Commons license, and indicate if changes were made.

\section{References}

1. Faloye FD, Kana EBG, Schmidt S (2013) Optimization of hybrid inoculum development techniques for biohydrogen production and preliminary scale up. Int J Hydrog Energy 38:11765-11773. https://doi.org/10.1016/j.ijhydene.2013.06.129

2. Faloye FD, Kana EBG, Schmidt S (2014) Optimization of biohydrogen inoculum development via a hybrid $\mathrm{pH}$ and microwave treatment technique-semi pilot scale production assessment. Int J Hydrog Energy 39:5607-5616. https://doi.org/10.1016/j. ijhydene.2014.01.163

3. Ghimire A, Frunzo L, Pirozzi F, Trably E, Escudie R, Lens PNL et al (2015) A review on dark fermentative biohydrogen production from organic biomass: process parameters and use of by-products. Appl Energy 144:73-95. https://doi.org/10.1016/j.apene rgy.2015.01.045

4. Sveinsdottir M, Beck SR, Orlygsson J (2009) Ethanol production from monosugars and lignocellulosic biomass by thermophilic bacteria isolated from Icelandic hot springs. Icel Agric Sci 22:45-58

5. Łukajtis R, Hołowacz I, Kucharska K, Glinka M, Rybarczyk P, Przyjazny A et al (2018) Hydrogen production from biomass using dark fermentation. Renew Sustain Energy Rev 91:665-694. https ://doi.org/10.1016/J.RSER.2018.04.043

6. Kucharska K, Hołowacz I, Konopacka-Łyskawa D, Rybarczyk P, Kami M (2018) Key issues in modeling and optimization of lignocellulosic biomass fermentative conversion to gaseous biofuels. Renew Energy. https://doi.org/10.1016/j.renene.2018.06.018 
7. Kucharska K, Rybarczyk P, Hołowacz I, Łukajtis R, Glinka M, Kamiński M (2018) Pretreatment of lignocellulosic materials as substrates for fermentation processes. Molecules 23:2937. https ://doi.org/10.3390/molecules23112937

8. Kucharska K, Hołowacz I, Konopacka-Łyskawa D, Rybarczyk P, Kamiński M (2018) Key issues in modeling and optimization of lignocellulosic biomass fermentative conversion to gaseous biofuels. Renew Energy 129:384-408. https://doi.org/10.1016/j. renene.2018.06.018

9. Kabir MM, Rajendran K, Taherzadeh MJ, Horváth IS (2015) Experimental and economical evaluation of bioconversion of forest residues to biogas using organosolv pretreatment. Bioresour Technol 178:201-208. https://doi.org/10.1016/j. biortech.2014.07.064

10. Logan BE (2004) Extracting hydrogen and electricity from renewable resources. Environ Sci Technol 38:4-8

11. Sinha P, Pandey A (2011) An evaluative report and challenges for fermentative biohydrogen production. Int J Hydrog Energy 36:7460-7478. https://doi.org/10.1016/j.ijhydene.2011.03.077

12. Kapdan IK, Kargi F (2006) Bio-hydrogen production from waste materials. Enzyme Microb Technol 38:569-582. https ://doi.org/10.1016/j.enzmictec.2005.09.015

13. Momirlan M, Veziroglu $T$ (2002) Current status of hydrogen energy. Renew Sustain Energy Rev 6:141-179. https://doi. org/10.1016/S1364-0321(02)00004-7

14. Pääkkönen A, Tolvanen $H$, Rintala J (2018) Techno-economic analysis of a power to biogas system operated based on fluctuating electricity price. Renew Energy 117:166-174. https:// doi.org/10.1016/j.renene.2017.10.031

15. Logan BE, Call D, Cheng S, Hamelers HVM, Sleutels THJA, Jeremiasse AW et al (2008) Microbial electrolysis cells for high yield hydrogen gas production from organic matter. Environ Sci Technol 42:8630-8640. https://doi.org/10.1021/es801553z

16. Nath K, Muthukumar M, Kumar A, Das D (2008) Kinetics of twostage fermentation process for the production of hydrogen. Int J Hydrog Energy 33:1195-1203. https://doi.org/10.1016/j. ijhydene.2007.12.011

17. Oztekin R, Kapdan IK, Kargi F, Argun H (2008) Optimization of media composition for hydrogen gas production from hydrolyzed wheat starch by dark fermentation. Int J Hydrog Energy 33:4083-4090. https://doi.org/10.1016/j.ijhydene.2008.05.052

18. Ren NQ, Chua H, Chan SY, Tsang YF, Wang YJ, Sin N (2007) Assessing optimal fermentation type for bio-hydrogen production in continuous-flow acidogenic reactors. Bioresour Technol 98:1774-1780. https://doi.org/10.1016/j.biort ech.2006.07.026

19. Uyeda K, Rabinowitz JC (1971) Pyruvate-ferredoxin oxidoreductase. IV. Studies on the reaction mechanism. J Biol Chem 246:3120-3125

20. Chong PS, Jahim JM, Harun S, Lim SS, Mutalib SA, Hassan $O$ et al (2013) Enhancement of batch biohydrogen production from prehydrolysate of acid treated oil palm empty fruit bunch. Int J Hydrog Energy 38:9592-9599. https://doi. org/10.1016/j.ijhydene.2013.01.154

21. Yang P, Zhang R, McGarvey JA, Benemann JR (2007) Biohydrogen production from cheese processing wastewater by anaerobic fermentation using mixed microbial communities. Int J Hydrog Energy 32:4761-4771. https://doi.org/10.1016/j. ijhydene.2007.07.038

22. Mohan SV, Babu VL, Sarma PN (2008) Effect of various pretreatment methods on anaerobic mixed microflora to enhance biohydrogen production utilizing dairy wastewater as substrate. Bioresour Technol 99:59-67. https://doi.org/10.1016/j.biort ech.2006.12.004

23. Favaro L, Alibardi L, Lavagnolo MC, Casella S, Basaglia $M$ (2013) Effects of inoculum and indigenous microflora on hydrogen production from the organic fraction of municipal solid waste. Int J Hydrog Energy 38:11774-11779. https://doi. org/10.1016/j.ijhydene.2013.06.137

24. Hawkes FR, Hussy I, Kyazze G, Dinsdale R, Hawkes DL (2007) Continuous dark fermentative hydrogen production by mesophilic microflora: principles and progress. Int J Hydrog Energy 32:172-184. https://doi.org/10.1016/j.ijhydene.2006.08.014

25. Łukajtis R, Rybarczyk P, Kucharska K, Konopacka-Łyskawa D, Słupek E, Wychodnik K et al (2018) Optimization of saccharification conditions of lignocellulosic biomass under alkaline pre-treatment and enzymatic hydrolysis. Energies. https://doi. org/10.3390/en 11040886

26. Łukajtis R, Kucharska K, Hołowacz I, Rybarczyk P, Wychodnik $\mathrm{K}$, Słupek E et al (2018) Comparison and optimization of saccharification conditions of alkaline pre-treated triticale straw for acid and enzymatic hydrolysis followed by ethanol fermentation. Energies 11:639. https://doi.org/10.3390/en11030639

27. Grzelka A, Sówka I, Miller U (2018) Metody oceny emisji odorów z obiektów gospodarki hodowlanej. Inżynieria Ekologiczna 19:56-64

28. Sówka I (2011) Methods of identification of odour gases emitted from industrial plants. Prace Naukowe Instytutu Inżynierii Ochrony Środowiska Politechniki Wrocławskiej. Monografie vol 90, nr 55

29. Gebicki J, Dymerski T (2016) Application of chemical sensors and sensor matrixes to air quality evaluation, vol 73. Elsevier, New York. https://doi.org/10.1016/bs.coac.2016.02.007

30. Gebicki J (2016) Trends in analytical chemistry application of electrochemical sensors and sensor matrixes for measurement of odorous chemical compounds. Trends Anal Chem 77:1-13. https://doi.org/10.1016/j.trac.2015.10.005

31. Kucharska K, Łukajtis R, Słupek E, Cieśliński H, Rybarczyk $P_{\text {, }}$ Kamiński M (2018) Hydrogen production from energy poplar preceded by MEA pre-treatment and enzymatic hydrolysis. Molecules 23:1-21. https://doi.org/10.3390/molecules 231130 29

32. Łukajtis R, Hołowacz I, Kucharska K, Glinka M, Rybarczyk $P$, Przyjazny A et al (2018) Corrigendum to "Hydrogen production from biomass using dark fermentation" [Renew Sustain Energy Rev 91 (2018) 665-94]. Renew Sustain Energy Rev. https://doi.org/10.1016/j.rser.2018.06.030

33. Zheng Y, Zhao J, Xu F, Li Y (2014) Pretreatment of lignocellulosic biomass for enhanced biogas production. Prog Energy Combust Sci 42:35-53. https://doi.org/10.1016/j. pecs.2014.01.001

34. Khaleb N, Jahim J, Kamal S (2012) Biohydrogen production using hydrolysates of palm oil mill effluent (POME). J Asian Sci 2:705-710

35. Zhang JN, Li YH, Zheng HQ, Fan YT, Hou HW (2015) Direct degradation of cellulosic biomass to bio-hydrogen from a newly isolated strain Clostridium sartagoforme FZ11. Bioresour Technol 192:60-67. https://doi.org/10.1016/j.biortech.2015.05.034

36. Zhu H, Béland M (2006) Evaluation of alternative methods of preparing hydrogen producing seeds from digested wastewater sludge. Int J Hydrog Energy 31:1980-1988. https://doi. org/10.1016/j.ijhydene.2006.01.019

37. Qin Y, Zhang F, Chen Y, Zhou Y, Li J, Zhu A et al (2012) Hierarchically porous $\mathrm{CuO}$ hollow spheres fabricated via a one-pot template-free method for high-performance gas sensors. J Phys Chem C 116:11994-12000. https://doi.org/10.1021/jp212 029n

38. Bejaoui A, Guerin J, Zapien JA, Aguir K (2014) Theoretical and experimental study of the response of $\mathrm{CuO}$ gas sensor under ozone. Sens Actuators B Chem 190:8-15. https://doi. org/10.1016/J.SNB.2013.06.084 
39. http://www.duranelectronica.com/docs/56_2069_I-ficha sondeltox-v07.pdf. Accessed 17 Apr 2019

40. https://sgx.cdistore.com/. Accessed 17 Apr 2019

41. https://www.maritex.com.pl/product/attachment/33377/ tgs2611.pdf. Accessed 17 Apr 2019

42. Isobe K, Koba K, Ueda S, Senoo K, Harayama S, Suwa Y (2011) A simple and rapid GC/MS method for the simultaneous determination of gaseous metabolites. J Microbiol Methods 84:46-51. https://doi.org/10.1016/j.mimet.2010.10.009

43. Song C, Liu Q, Ji N, Deng S, Zhao J, Kitamura Y (2017) Natural gas purification by heat pump assisted MEA absorption process. Appl Energy 204:353-361. https://doi.org/10.1016/j. apenergy.2017.07.052

44. Yang M, Zhang W, Rosentrater K (2017) Anhydrous ammonia pretreatment of corn stover and enzymatic hydrolysis of glucan from pretreated corn stover. Fermentation 3:9. https ://doi.org/10.3390/fermentation3010009

45. Lin Z, Huang H, Zhang H, Zhang L, Yan L, Chen J (2010) Ball milling pretreatment of corn stover for enhancing the efficiency of enzymatic hydrolysis. Appl Biochem Biotechnol 162:1872-1880. https://doi.org/10.1007/s12010-010-8965-5

Publisher's Note Springer Nature remains neutral with regard to jurisdictional claims in published maps and institutional affiliations. 